\title{
Effects of rhIGF-I Administration on Bone Turnover During Short-Term Fasting
}

Steven K. Grinspoon, Howard B.A. Baum, Scott Peterson, and Anne Klibanski

Neuroendocrine Unit, Massachusetts General Hospital and Harvard Medical School, Boston, Massachusetts 02114

\section{Abstract}

Insulin-like growth factor-I (IGF-I) is a nutritionally dependent bone trophic hormone which stimulates osteoblast function and collagen synthesis in vivo and in vitro. We hypothesized that in the fasting state, IGF-I levels would decline significantly and would establish a model in which we could investigate the effects of IGF-I administration on bone turnover. We therefore studied 14 normal women ages 19-33 (mean, 24 \pm 4 [SD] years) during a complete 10-d fast. After $4 \mathrm{~d}$ of fasting, subjects were randomized to receive rhIGF-I or placebo subcutaneously twice a day for 6 d. Bone turnover was assessed using specific markers of formation (osteocalcin and type I procollagen carboxyl-terminal propeptide [PICP]) and resorption (pyridinoline, deoxypyridinoline, type I collagen crosslinked N-telopeptide [N-telopeptide] and hydroxyproline). Serum levels of PICP and osteocalcin decreased from $143 \pm 52$ to $60 \pm 28 \mathrm{ng} / \mathrm{ml}(P$ $=0.001)$ and from 7.6 \pm 5.4 to $4.2 \pm 3.1 \mathrm{ng} / \mathrm{ml}(P=0.001)$ respectively with $4 \mathrm{~d}$ of fasting. Urinary excretion of pyridinoline and deoxypyridinoline decreased from $96 \pm 63$ to $47 \pm 38 \mathrm{nmol} / \mathrm{mmol}$ creatinine $(P<0.05)$ and from $28 \pm 17$ to $14 \pm 11 \mathrm{nmol} / \mathrm{mmol}$ creatinine $(P<0.05)$ respectively. Mean IGF-I levels decreased from $310 \pm 81$ to $186 \pm 78 \mathrm{ng} /$ $\mathrm{ml}(\boldsymbol{P}=\mathbf{0 . 0 0 1})$.

In the second part of the experimental protocol, serum osteocalcin and PICP levels increased 5- and 3-fold, respectively with rhIGF-I administration and were significantly elevated compared with the placebo group at the end of treatment $(20.9 \pm 17.3 \mathrm{vs} .5 .9 \pm 6.4 \mathrm{ng} / \mathrm{ml}$ for osteocalcin $[P$ $<0.05]$ and $188 \pm 45$ vs. $110 \pm 37 \mathrm{ng} / \mathrm{ml}$ for PICP $[P<0.05])$. In contrast, all four markers of bone resorption, including urinary pyridinoline, deoxypyridinoline, $\mathrm{N}$-telopeptide and hydroxyproline were unchanged with rhIGF-I administration. This report is the first to demonstrate that bone turnover falls rapidly with acute caloric deprivation in normal women. RhIGF-I administration uncouples bone formation in this setting by significantly increasing bone formation, but not resorption. These data suggest a novel use of rhIGFI to selectively stimulate bone formation in states of undernutrition and low bone turnover. (J. Clin. Invest. 1995. 96:900-906.) Key words: insulin-like growth factor I • bone turnover $\cdot$ fasting $\cdot$ nutrition $\cdot$ osteocalcin

Address correspondence to Anne Klibanski, M.D., Neuroendocrine Unit, Massachusetts General Hospital, Boston, MA 02114. Phone: 617-7263870; FAX: 617-726-5072.

Received for publication 14 March 1995 and accepted in revised form 12 April 1995.

J. Clin. Invest.

(c) The American Society for Clinical Investigation, Inc. 0021-9738/95/08/0900/07 \$2.00

Volume 96, August 1995, 900-906

\section{Introduction}

Insulin-like growth factor-I (IGF-I) is a critical endocrine factor in the physiological regulation of bone formation with potent effects on bone growth and remodeling. IGF-I acts through specific receptors on cells of osteoblast lineage to stimulate collagen synthesis (1-4) and increase proliferation and differentiation of osteoblast precursor cells (5-7). IGF-I also functions as a paracrine factor in the local regulation of bone metabolism. Osteoblast transcription of IGF-I increases in response to stimulation by parathyroid hormone (PTH), growth hormone (GH) ${ }^{1}$ and estrogen (8-12). In turn, locally produced IGF-I may act to oppose the effects of PTH on osteoblasts $(13,14)$.

The regulation of IGF-I is nutritionally dependent and circulating levels of IGF-I decline after acute fasting due to acquired GH resistance and increase with nutritional repletion (15-18). In severe chronic undernutrition, IGF-I concentrations decrease in association with low bone turnover and significant bone loss (19-23). Similarly, bone turnover is diminished in other pathologic states in which IGF-I levels are deficient because of an inherited resistance to the action of $\mathrm{GH}$ or in association with decreased GH secretion (24-28). These data suggest that IGFI is an important modulator of normal bone metabolism and that a deficiency of IGF-I at systemic and/or tissue levels may contribute to abnormal bone metabolism in undernutrition. Recent experimental data demonstrate that recombinant human IGF-I (rhIGF-I) increases bone turnover in menopausal women (29). However, the effects of rhIGF-I on bone turnover in undernutrition and other pathologic conditions of low bone turnover have not been investigated.

We hypothesized that in the fasting state, IGF-I levels would decline significantly and would establish a model in which we could investigate the acute effects of IGF-I administration on bone turnover. Subjects were fasted for four days before randomization to treatment with rhIGF-I or placebo. Bone turnover was assessed at baseline and then again before and after treatment with rhIGF-I. Glomerular filtration rate (GFR) and fractional tubular reabsorption of calcium were also determined to assess renal handling of calcium during rhIGF-I therapy. Our findings demonstrate: $(a)$ a significant decrease in indices of both bone formation and resorption during short-term fasting and $(b)$ rhIGF-I administration uncouples bone formation and is a potent and selective osteoblast stimulator in states of acute undernutrition.

\section{Methods}

\section{Experimental subjects}

We studied 14 women with a mean age of $24 \pm 4 \mathrm{yr}$, range 19-33 yr. All patients gave written consent as approved by the Subcommittee on

1. Abbreviations used in this paper: \%IBW, percent ideal body weight; ANOVA, analysis of variance; GFR, glomerular filtration rate; GH, growth hormone; IGFBP, insulin-like growth factor binding protein; PICP, type I procollagen carboxyl-terminal propeptide. 
Human Studies of the Massachusetts General Hospital. Subjects weighed between $96-132 \%$ of ideal body weight (mean, $115 \pm 10 \%$ ), as defined by the Metropolitan Life Insurance Tables of Height and Weight (30). Each participant was in good health without any acute or chronic medical conditions, was on no medication at the time of the study and had not received glucocorticoids or any other medication known to affect bone metabolism. All subjects had normal menstrual function assessed by clinical history and normal thyroid function determined by clinical exam and a thyroid stimulating hormone level. Patients with a history of oral contraceptive use within $6 \mathrm{mo}$ of the study, prior anorexia nervosa or bulimia or recent history of trauma or bone fracture were excluded.

\section{Experimental design}

Subjects were admitted to the General Clinical Research Center of the Massachusetts General Hospital and then underwent a two-part sequential protocol.

Part I. Acute fasting. In the first part of the protocol, subjects underwent a total fast for $4 \mathrm{~d}$ except for water ad libidum. 20 meq of oral potassium chloride and $200 \mathrm{mg}$ of allopurinol were administered daily to prevent hypokalemia and hyperuricemia, respectively. In addition, a standard multivitamin containing 400 USP units of ergocalciferol was administered daily throughout the protocol to provide essential vitamins and minerals. Patients were encouraged to ambulate throughout the protocol.

Part II. Response to rhIGF-I administration. In the second part of the protocol, beginning on the fifth day of the fast, subjects were randomized to receive either rhIGF-I $100 \mu \mathrm{g} / \mathrm{kg}$ (Genentech, San Francisco, CA) or a saline placebo subcutaneously at 1000 and $2200 \mathrm{~h}$. Subjects were blinded to randomization. Immediately before the first injection of rhIGF-I, a continuous infusion of $5 \%$ glucose $/ 0.45 \%$ normal saline was begun at $50 \mathrm{cc} / \mathrm{h}$ to prevent hypoglycemia. Blood glucose was checked by an Accucheck III meter (Boehringer Manheim, Indianapolis, IN) every $30 \mathrm{~min}$ for $2 \mathrm{~h}$ and then 4 and $8 \mathrm{~h}$ after each injection of IGF-I or placebo. The concentration and rate of the glucose infusion were adjusted on a sliding scale to maintain serum glucose $>60 \mathrm{mg} /$ $\mathrm{dl}$ in both IGF-I and placebo groups. The maximum infusion in any patient was $10 \%$ glucose $/ 0.45 \%$ normal saline at $75 \mathrm{cc} / \mathrm{h}$.

Experimental endpoints. Serum electrolytes, calcium, phosphorus, IGF-I and insulin-like growth factor binding protein-3 (IGFBP-3) levels were measured at baseline (day 1) and daily on days 5-11. Serum ionized calcium levels were available on days 5,8 , and 11 . Serum osteocalcin, PICP, PTH, 25-hydroxyvitamin D and 1, 25-dihydroxyvitamin D levels were measured at baseline and days 5, 8, and 11. Insulin levels were measured on days 8 and $11.24 \mathrm{~h}$ urine measurements for calcium, pyridinoline and deoxypyridinoline were made from 0800 to $0800 \mathrm{~h}$ on days $1-2,4-5,7-8$, and $10-11$. To further assess bone resorption during rhIGF-I administration, hydroxyproline and N-telopeptide levels were measured in urine samples collected on days 5,8 , and 11 of the study. Glomerular filtration rate (GFR), calcium filtration and fractional tubular reabsorption of calcium were calculated on days 5,8 , and 11 to determine the effects of rhIGF-I on renal calcium handling (see Appendix) (31). Weight was measured daily and percent ideal body weight (\%IBW) was calculated at baseline and days 5 and 11 .

\section{Laboratory methods}

Serum total and ionized calcium, phosphorus, electrolytes, PTH, 25 hydroxyvitamin D, 1,25 dihydroxyvitamin D and insulin levels were measured using published methods (32). Serum IGF-I was measured after an acid-alcohol extraction using a RIA kit with an intra-assay coefficient of variation $2.4-3.0 \%$ (Corning Nichols Institute). PICP was measured using a RIA kit with an intra-assay coefficient of variation of 2.1-3.2\% (Incstar, Stillwater, MN). Osteocalcin was measured using a RIA kit with an intra-assay coefficient of variation of $5.7-8.1 \%$ (Corning Nichols Institute). Urinary excretion of pyridinoline and deoxypyridinoline were measured according to the methods of Uebelhart et al. and modified by Corning Nichols Institute (33). Urinary excretion of $\mathrm{N}$-telopeptide was measured by ELISA with a coefficient of variation
Table I. Clinical and Biochemical Responses to Four Days of Fasting

\begin{tabular}{lcccc}
\hline \multicolumn{1}{c}{ Variable } & Baseline & Day 5* & $\begin{array}{c}P \\
\text { value }^{\ddagger}\end{array}$ & $\begin{array}{c}\text { Normal } \\
\text { range }^{\text {s }}\end{array}$ \\
\hline Weight (kg) & $64.1 \pm 7.8$ & $60.0 \pm 7.4$ & 0.001 & \\
\% IBW & $115 \pm 10$ & $108 \pm 10$ & 0.001 & \\
IGF-I (ng/ml) & $310 \pm 81$ & $186 \pm 78$ & 0.001 & $112-450$ \\
IGFBP-3 (ng/ml) & $3162 \pm 466$ & $3075 \pm 508$ & 0.35 & $2300-5300$ \\
Serum calcium (mg/dl) & $8.9 \pm 0.3$ & $9.1 \pm 0.3$ & 0.03 & $8.5-10.5$ \\
Serum phosphorus (mg/dl) & $4.0 \pm 0.7$ & $3.6 \pm 0.3$ & 0.03 & $2.6-4.5$ \\
Urinary calcium (mg/d) & $98 \pm 61$ & $172 \pm 85$ & 0.04 & $0.0-300$ \\
Serum bicarbonate (meq/) & $27.5 \pm 1.7$ & $18.2 \pm 3.4$ & 0.001 & $22-26$ \\
PTH (pg/ml) & $40 \pm 11$ & $15 \pm 7$ & 0.001 & $10-60$ \\
25-hydroxyvitamin D (ng/ml) & $18 \pm 7$ & $22 \pm 9$ & 0.004 & $8-55$ \\
1,25-dihydroxyvitamin D & & & & \\
$\quad$ (pg/ml) & $28 \pm 9$ & $32 \pm 10$ & 0.28 & $16-42$ \\
PICP (ng/ml) & $143 \pm 52$ & $60 \pm 28$ & 0.001 & $50-170$ \\
Osteocalcin (ng/ml) & $7.6 \pm 5.4$ & $4.2 \pm 3.1$ & 0.001 & $0.4-8.2$ \\
Pyridinoline (nmol/mmol cr) & $96 \pm 63$ & $47 \pm 38$ & 0.02 & $22-89$ \\
Deoxypyridinoline & & & & \\
$\quad$ (nmol/mmol cr) & $28 \pm 17$ & $14 \pm 11$ & 0.02 & $4-21$ \\
GFR (mL/min) & $97 \pm 25$ & $70 \pm 23$ & 0.01 & \\
& & & &
\end{tabular}

The results are mean \pm SD. * Assessment made prior to the initiation of rhIGF-I administration $(n=14)$. ${ }^{\ddagger} P$ values for comparison of Baseline vs. day 5 by the Wilcoxon Signed-Rank test. ${ }^{8}$ In premenopausal women. $c r$, creatinine. GFR, glomerular filtration rate.

of 7.9-11.2\% (Corning Nichols Institute). Urinary excretion of total hydroxyproline was measured by colorimetric assay with a coefficient of variation of $8.4-9.9 \%$ (Corning Nichols Institute). IGFBP-3 was measured using a RIA kit with an intra-assay coefficient of variation of 5.3-6.7\% (Diagnostic Systems Laboratories, Webster, TX). All samples for hormone determinations from a single individual were measured in duplicate and run in the same assay. Normal values for each assay are shown in Table I.

\section{Statistical methods}

The effects of rhIGF-I administration on experimental endpoints were determined using a mixed model analysis of variance (ANOVA). The random effects were subjects and time $\times$ subjects and the fixed effects were treatment, time, and time $\times$ treatment. The effect of treatment on each end point was measured by the time $\times$ treatment effect with the time $\times$ subject effect as an error term. Treatment groups were also compared by the Mann-Whitney test. To determine the effects of acute fasting, the changes in study endpoints from baseline (day 1) to day 5 (before the initiation of thIGF-I) were compared in all subjects using the Wilcoxon Signed-Rank test. Unless noted otherwise, results are expressed as mean \pm SD.

\section{Results}

\section{Baseline clinical data}

Baseline clinical and biochemical data for the entire study group are shown in Table I. At baseline, serum IGF-I, IGFBP-3, and markers of bone turnover, calcium metabolism and weight did not differ significantly in the rhIGF-I and placebo groups.

\section{Part I. Acute fasting}

Metabolic. Clinical and biochemical responses to $4 \mathrm{~d}$ of acute fasting are shown in Table I. Mean weight loss was 4.1 \pm 0.7 $\mathrm{kg}$ and represented a $7 \%$ decrease in IBW $(P=0.001)$. Serum IGF-I levels decreased by $40 \%(P=0.001)$, but serum IGFBP-3 levels did not change significantly with fasting (Table I, Fig. 1).

Bone turnover. Markers of bone formation and resorption 

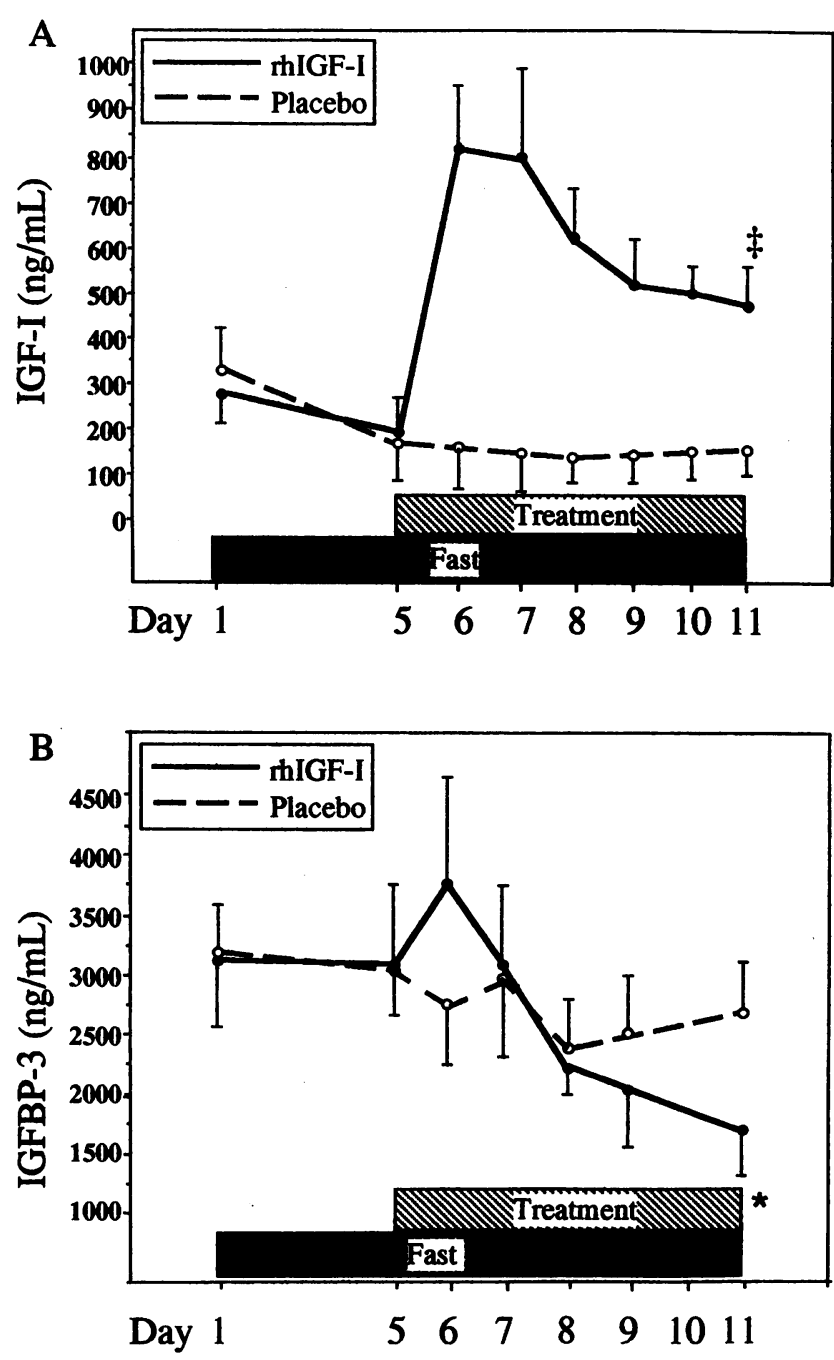

Figure 1. Serum IGF-I and IGFBP-3 levels in response to fasting and rhIGF-I administration. ( $A$ ) IGF-I at baseline and days 5-11 of the study. (B) IGFBP-3 at baseline and days 5-9 and 11 of the study. Error bars represent mean \pm 1 SD. $* P<0.05$ and $\ddagger P<0.01$ vs. Placebo by the Mann-Whitney test.

decreased significantly after 4 days of fasting (Fig. 2). Serum levels of osteocalcin and PICP fell by $45 \%$ and $58 \%$ respectively $(P=0.001$ for each variable, Table $I)$. Urinary excretion of pyridinoline and deoxypyridinoline also decreased significantly with fasting (Table I). Serum calcium levels increased and PTH levels decreased significantly in association with an increase in urinary calcium levels (Table I). Serum levels of 25-hydroxyvitamin D increased significantly with fasting and a single multivitamin per day, but levels of 1,25-dihydroxyvitamin D did not change significantly with acute fasting (Table I).

\section{Part II. Response to rhIGF-I administration}

Metabolic. Serum IGF-I levels peaked on the first day after treatment was begun in subjects receiving rhIGF-I and remained significantly elevated compared to the placebo group throughout the treatment period (Fig. 1). IGFBP-3 levels were significantly decreased in women receiving rhIGF-I compared with placebo at the conclusion of the study (Fig. 1). Despite the infusion of glucose, insulin levels were suppressed in both groups and were not significantly different (Table II). Percent ideal body weight was also not significantly different in subjects receiving rhIGFI compared with placebo. Serum bicarbonate levels normalized in both groups by day 8 of the protocol and were not significantly different in a comparison of subjects receiving rhIGF-I vs. placebo.

Bone turnover. The rate of change of osteocalcin ( $P$ $<0.05)$ and PICP $(P<0.001)$ was significantly greater in the subjects who received rhIGF-I compared with the placebo group using a mixed model analysis of variance. In addition, serum osteocalcin and PICP levels were significantly higher in the rhIGF-I group compared to the placebo group at the conclusion of the study (Table II, Fig. 2). Urinary excretion of pyridinoline, deoxypyridinoline, $\mathrm{N}$-telopeptide and hydroxyproline did not change significantly in either group (Table II, Fig. 2 ).

The rate of change in ionized calcium, phosphorus, and PTH levels as well as urinary calcium excretion did not differ with respect to treatment by ANOVA (Table II). Comparison between the treatment groups by the Mann-Whitney test on the final day of the study demonstrated that ionized calcium levels and urinary calcium excretion were higher in the rhIGF-I-treated group compared to the placebo group $(P<0.05)$, although both were decreased from baseline. In contrast, serum PTH levels were lower in the rhIGF-I-treated group $(P<0.05)$. Serum calcium levels and 25-hydroxyvitamin D levels decreased significantly in the rhIGF-I treated patients compared to placebo $(P<0.05)$, but the rate of change in 1,25-dihydroxyvitamin D levels was not different between the treatment groups (Table II). The rate of change in GFR was significantly greater in subjects receiving rhIGF-I compared with placebo $(P$ $<0.05$ ) and mean GFR was significantly greater in the rhIGFI vs. placebo treated group at the conclusion of the study $[115 \pm 20$ vs. $88 \pm 17 \mathrm{ml} /$ minute $(P<0.05)]$ (Table II). The change in GFR remained significant when corrected for weight. Calcium filtration increased in parallel with GFR in both groups (Table II). However, fractional tubular reabsorption of calcium was decreased in the rhIGF-I-treated patients compared with controls at the conclusion of the study $[98.54 \pm 0.83$ vs. 99.18 $\pm 0.29 \%(P=0.07)$ (Table II).

Side effects. No significant side effects attributable to rhIGFI administration occurred. Serum glucose levels were maintained above $60 \mathrm{mg} / \mathrm{dl}$ in all study subjects and no subjects experienced joint aches, fluid retention, parotid swelling or any other side effects of rhIGF-I administration. One woman in the placebo group and one in the rhIGF-I group dropped out on the fifth day, prior to randomization, because of an unwillingness to continue the fast. One additional woman in rhIGF-I group was discontinued from the protocol on day 10 when she developed an upper respiratory tract infection.

\section{Discussion}

Our results demonstrate that there is a profound decrease in biochemical indices of both bone formation and resorption during acute fasting and that rhIGF-I administration selectively stimulates bone formation in this setting. The rapid decrease in bone turnover in young women during fasting is a significant new observation. Serum levels of PICP and osteocalcin fell by 58 and $45 \%$, respectively after only $4 \mathrm{~d}$ of fasting. Urine markers of bone resorption also fell by a similar order of magnitude, indicating that acute undernutrition has parallel effects on both bone formation and resorption. These observations are in 

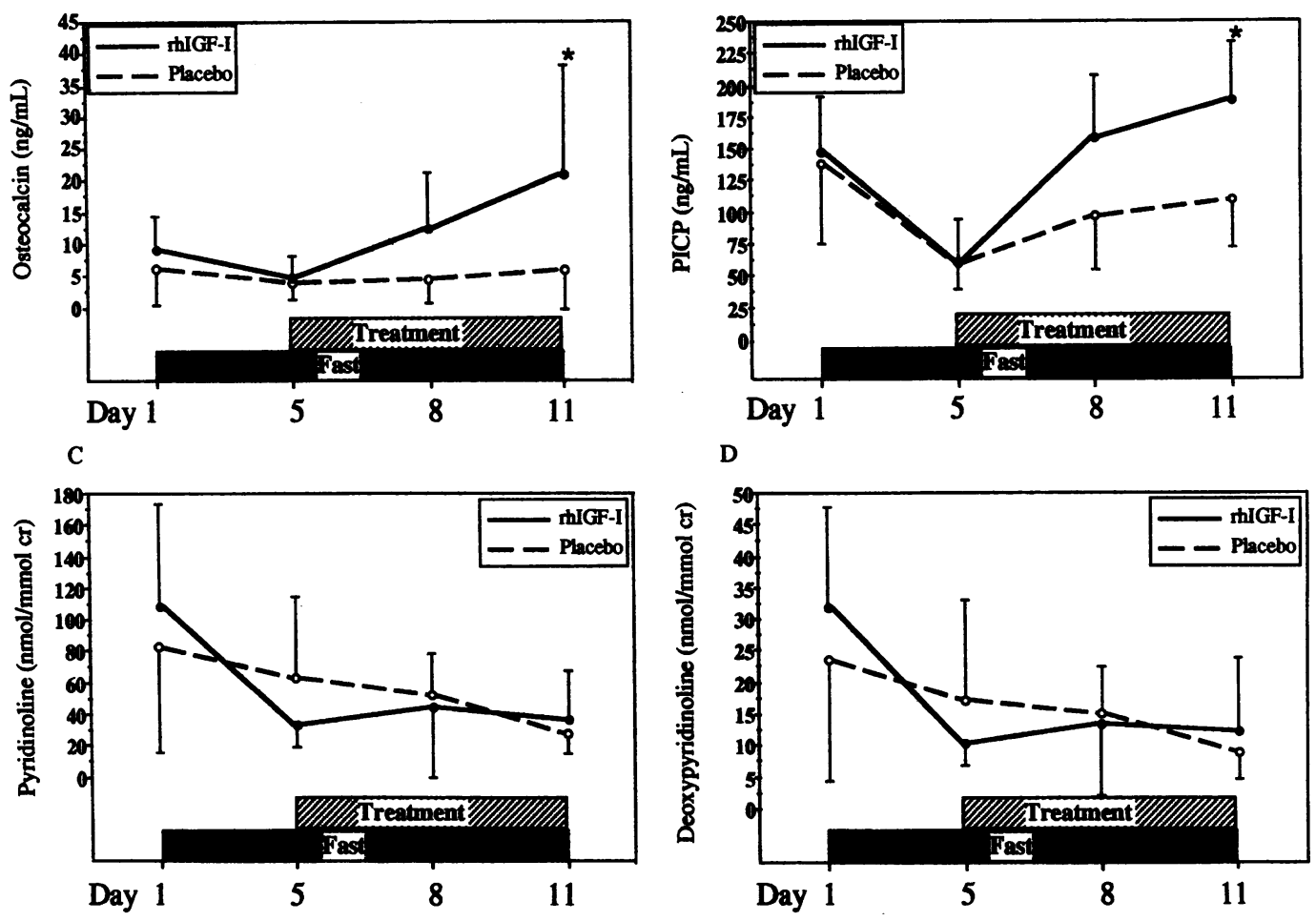

Figure 2. The effects of short-term fasting and rhIGF-I administration on biochemical indices of bone turnover. ( $A$ ) Serum levels of osteocalcin at baseline and days 5, 8, and 11 of the study. $(B)$ Serum levels of PICP at baseline and days 5, 8, and 11 of the study. $(C)$ Urinary excretion of pyridinoline at baseline and days 5,8 , and 11 of the study. $(D)$ Urinary excretion of deoxypyridinoline at baseline and days 5 , 8 , and 11 of the study. Error bars represent mean \pm 1 SD. ${ }^{*} P<0.05$ vs. Placebo by the Mann-Whitney test.

agreement with recent animal data in which bone collagen mRNA expression was shown to decline significantly after $4 \mathrm{~d}$ of fasting and with in vivo data showing decreased markers of bone resorption in malnourished children and provide further evidence for the important affects of acute undernutrition on bone metabolism (34-37).

One potential mechanism to explain the decline in bone turnover with short-term fasting is a decrease in systemic and/ or local bone IGF-I concentrations. Serum IGF-I concentrations are nutritionally dependent $(15,17)$ and decreased significantly after $4 \mathrm{~d}$ of fasting. Potent effects of IGF-I on osteoblast function and differentiation in vitro $(2,3,5,7)$ and bone protein synthesis and cancellous bone formation in animals and in humans have recently been demonstrated $(29,38,39)$. Our finding of decreased serum and urine markers of bone turnover is consistent with biochemical data from other pathologic conditions associated with deficient IGF-I concentrations $(25,28)$. In addition, fasting-induced changes in IGF-I or its binding proteins may also affect bone turnover at the tissue level through local autocrine and paracrine actions (40-42). Serum levels of IGFBP-3, a key determinant of free IGF-I tissue availability (43), were constant while total IGF-I levels decreased during fasting. These data suggest that the percentage of free IGF-I available to bone tissue might have fallen to an even greater extent than reflected in total IGF-I levels. Fasting could also decrease bone turnover through an effect on a second IGF binding protein, IGFBP-1. Serum and local tissue levels of IGFBP1 are known to increase with fasting as a result of decreased serum insulin levels $(20,44)$. Recent animal data have demon- strated that increased IGFBP-1 levels during fasting inhibit collagen synthesis by affecting local binding of IGF-I binding to its receptor $(36,45)$. Therefore, declining free IGF-I concentrations in bone tissue or activation of a local inhibitor to bone formation, such as IGFBP-1, may be one of the causes of the dramatic decrease in bone metabolism observed with fasting.

Additional mechanisms impacting on the fall in bone turnover with fasting include changes in serum PTH levels and acid base status. Serum and urinary calcium levels increased after $4 \mathrm{~d}$ of fasting in association with decreased PTH levels. The likeliest explanation for the decline in serum PTH levels was the increase in serum calcium levels. One potential mechanism suggested by studies in experimental animals to explain the increase in serum calcium is a direct effect of acidosis to demineralize bone (46). Recent studies in postmenopausal women have demonstrated that acidosis might have a PTH-independent effect to alter bone metabolism (47).

A critical observation in this study is the effect of IGF-I administration to increase bone formation and uncouple bone formation and resorption in acute fasting. Serum osteocalcin levels increased fivefold and PICP levels increased threefold during rhIGF-I administration, demonstrating the significant effect of rhIGF-I to increase bone formation in this experimental model. In contrast, sensitive markers of osteoclast activation and collagen degradation did not increase with rhIGF-I administration, consistent with the known effect of rhIGF-I to decrease collagen degradation in vitro (8). Serum ionized calcium levels and urinary calcium excretion decreased in both treatment groups and did not differ by analysis of variance. In addition, 
Table II. Clinical and Biochemical Responses to rhIGF-I Administration

\begin{tabular}{|c|c|c|c|}
\hline Variable & Day 5 & Day 8 & Day 11 \\
\hline \multicolumn{4}{|l|}{ Weight (kg) } \\
\hline rhIGF-I & $58.8 \pm 4.9$ & ND & $61.6 \pm 4.9$ \\
\hline Placebo & $61.2 \pm 9.6$ & ND & $58.2 \pm 7.1$ \\
\hline \multicolumn{4}{|l|}{ Insulin $(\mu \mathrm{IU})$} \\
\hline rhIGF-I & ND & $7 \pm 5$ & $<5$ \\
\hline Placebo & ND & $5 \pm 0$ & $<5$ \\
\hline \multicolumn{4}{|c|}{ Serum calcium (mg/dl) } \\
\hline rhIGF-I & $9.1 \pm 0.3$ & $8.6 \pm 0.3$ & $8.8 \pm 0.3^{*}$ \\
\hline Placebo & $9.0 \pm 0.3$ & $8.9 \pm 0.2$ & $9.0 \pm 0.3$ \\
\hline \multicolumn{4}{|c|}{ Ionized calcium (mmol/liter) } \\
\hline rhIGF-I & $1.23 \pm .04$ & $1.25 \pm .04$ & $1.22 \pm .03$ \\
\hline Placebo & $1.20 \pm .04$ & $1.17 \pm .03$ & $1.17 \pm .03$ \\
\hline \multicolumn{4}{|c|}{ Serum phosphorus (mg/dl) } \\
\hline rhIGF-I & $3.6 \pm 0.3$ & $3.7 \pm 0.4$ & $3.9 \pm 0.9$ \\
\hline Placebo & $3.6 \pm 0.4$ & $3.8 \pm 0.5$ & $4.1 \pm 0.5$ \\
\hline \multicolumn{4}{|c|}{ Urinary calcium (mg/d) } \\
\hline rhIGF-I & $173 \pm 92$ & $104 \pm 58$ & $125 \pm 48$ \\
\hline Placebo & $170 \pm 84$ & $73 \pm 23$ & $52 \pm 16$ \\
\hline \multicolumn{4}{|l|}{ PTH (pg/ml) } \\
\hline rhIGF-I & $13 \pm 8$ & $14 \pm 7$ & $11 \pm 4$ \\
\hline Placebo & $17 \pm 6$ & $22 \pm 7$ & $24 \pm 8$ \\
\hline \multicolumn{4}{|l|}{ GFR (ml/min) } \\
\hline rhIGF-I & $69 \pm 21$ & $108 \pm 24$ & $115 \pm 20^{*}$ \\
\hline Placebo & $71 \pm 27$ & $96 \pm 36$ & $88 \pm 17$ \\
\hline \multicolumn{4}{|c|}{ Calcium filtration $(\mathrm{mg} / \mathrm{min})$} \\
\hline rhIGF-I & $3.8 \pm 1.1$ & $5.9 \pm 1.4$ & $6.3 \pm 1.1^{*}$ \\
\hline Placebo & $3.8 \pm 1.6$ & $5.0 \pm 1.9$ & $4.6 \pm 1.0$ \\
\hline \multicolumn{4}{|c|}{$\begin{array}{l}\text { Fractional reabsorption of } \\
\text { calcium (\%) }\end{array}$} \\
\hline rhIGF-I & $96.65 \pm 1.84$ & $98.90 \pm 0.66$ & $98.54 \pm 0.83$ \\
\hline Placebo & $96.49 \pm 1.76$ & $98.83 \pm 0.67$ & $99.18 \pm 0.29$ \\
\hline \multicolumn{4}{|c|}{ 25-hydroxyvitamin D (ng/ml) } \\
\hline rhIGF-I & $27 \pm 8$ & $19 \pm 6$ & $21 \pm 8^{\ddagger}$ \\
\hline Placebo & $17 \pm 7$ & $16 \pm 7$ & $17 \pm 7$ \\
\hline \multicolumn{4}{|c|}{$\begin{array}{l}\text { 1,25-dihydroxyvitamin D } \\
(\mathrm{pg} / \mathrm{ml})\end{array}$} \\
\hline rhIGF-I & $34 \pm 10$ & $36 \pm 5$ & $27 \pm 7$ \\
\hline Placebo & $30 \pm 11$ & $36 \pm 9$ & $27 \pm 5$ \\
\hline \multicolumn{4}{|l|}{ PICP (ng/ml) } \\
\hline rhIGF-I & $61 \pm 21$ & $158 \pm 50$ & $188 \pm 45^{\ddagger}$ \\
\hline Placebo & $60 \pm 34$ & $97 \pm 43$ & $110 \pm 37$ \\
\hline \multicolumn{4}{|l|}{ Osteocalcin (ng/ml) } \\
\hline rhIGF-I & $4.8 \pm 3.4$ & $12.6 \pm 8.6$ & $20.9 \pm 17.3 *$ \\
\hline Placebo & $3.6 \pm 2.9$ & $4.9 \pm 3.7$ & $5.9 \pm 6.4$ \\
\hline \multicolumn{4}{|c|}{ Pyridinoline $(\mathrm{nmol} / \mathrm{mmol} \mathrm{cr})$} \\
\hline rhIGF-I & $33 \pm 14$ & $44 \pm 45$ & $37 \pm 30$ \\
\hline Placebo & $63 \pm 52$ & $53 \pm 26$ & $28 \pm 13$ \\
\hline \multicolumn{4}{|c|}{$\begin{array}{l}\text { Deoxypyridinoline (nmol/ } \\
\text { mmol cr) }\end{array}$} \\
\hline rhIGF-I & $10 \pm 4$ & $13 \pm 12$ & $12 \pm 11$ \\
\hline Placebo & $17 \pm 16$ & $15 \pm 8$ & $9 \pm 5$ \\
\hline \multicolumn{4}{|c|}{ N-Telopeptide (BCE) } \\
\hline rhIGF-I & $60 \pm 32$ & $72 \pm 43$ & $56 \pm 53$ \\
\hline Placebo & $94 \pm 104$ & $71 \pm 52$ & $82 \pm 87$ \\
\hline \multicolumn{4}{|c|}{ Hydroxyproline/creatinine } \\
\hline rhIGF-I & $0.036 \pm 0.013$ & $0.037 \pm 0.021$ & $0.038 \pm 0.015$ \\
\hline Placebo & $0.051 \pm 0.048$ & $0.036 \pm 0.027$ & $0.028 \pm 0.013$ \\
\hline
\end{tabular}

The results are presented as mean \pm SD. ${ }^{*} P<0.05$ and ${ }^{\ddagger} P<0.001$ in a comparison of treatment effects from day 5 to day 11 by ANOVA. Weight and insulin levels were compared by the Mann-Whitney test on day 11 . Measurements on day 5 were made after $4 \mathrm{~d}$ of fasting and immediately before the initiation of rhIGF-I administration. $N D$, not done. $c r$, creatinine. $B C E$, bone collagen equivalent. GFR, glomerular filtration rate. serum calcium levels were significantly lower in response to treatment with rhIGF-I than in the placebo-treated group. Taken together, these data provide additional evidence against increased resorption.

Although urinary calcium excretion decreased in both treatment groups, comparison on the final day of the study showed higher levels in the rhIGF-I-treated group than the placebo group. The most likely mechanism to explain the observed difference in urinary calcium excretion between the groups is an effect of rhIGF-I on renal calcium handling. GFR was significantly increased in the rhIGF-I group compared to placebo, consistent with the known effect of rhIGF-I to increase glomerular filtration (48). Calcium filtration increased in proportion to GFR but tubular reabsorption of calcium decreased. A second potential mechanism to explain the difference in urinary calcium excretion is an increase in calcium mobilization from bone through a systemic effect of rhIGF-I on hormone metabolism or a paracrine effect on local bone cytokines $(49,50)$. However, 25-hydroxyvitamin D and PTH levels were significantly decreased in the rhIGF-I-treated group compared to the placebo group and 1,25-dihydroxyvitamin D levels were not different between the groups. Furthermore, a biologically significant action of rhIGF-I to increase calcium release from bone independent of increased collagen degradation or osteoclast activation, as determined by four separate sensitive markers, is unlikely.

Our data demonstrate that rhIGF-I increased bone formation out of proportion to any detectable increase in resorption and therefore resulted in an uncoupling of bone formation and resorption in this experimental model. The effect of rhIGF-I administration on bone formation is likely the result of elevated serum and tissue concentrations of IGF-I in women receiving rhIGF-I compared to placebo. Because supraphysiological doses of IGF-I were used, we do not know what effects a smaller dose of rhIGF-I would have had on bone turnover but our data demonstrate that this dose of rhIGF-I uncouples bone turnover and selectively stimulate bone formation during short-term fasting. These data suggest that rhIGF-I may be an important form of therapy to investigate to increase bone formation in pathologic conditions of low bone turnover, such as chronic undernutrition and anorexia nervosa.

Other potentially important mechanisms to explain the effect of rhIGF-I on bone formation include modulation of free IGFI concentrations or potentiation of the effects of IGF-I at the local tissue level through an effect on IGF-I binding proteins. In this study, IGFBP-3 levels declined significantly over $6 \mathrm{~d}$ of rhIGF-I administration, consistent with prior data on the metabolic effects of rhIGF-I administration in caloric restriction (51). Therefore, the increase in tissue levels of free IGF-I could affect bone formation. It is unlikely that the observed effects of rhIGF-I administration on bone turnover were potentiated by insulin because insulin levels were equivalently suppressed in both treatment groups despite glucose infusion. However, caloric repletion may selectively stimulate bone formation in acute undernutrition without an effect on insulin levels. It is possible that even the small quantities of glucose administered in this study were enough to alter tissue levels of free IGF-I or related binding proteins and contribute to the increase in bone turnover.

Our findings contrast those reported by Ebeling et al. in which indices of bone formation and resorption both increased in postmenopausal women in response to six days of rhIGF-I administration (29). Similar IGF-I levels were achieved in both studies, suggesting that factors associated with gonadal status, 
age, fasting and/or undernutrition may uncouple the effects of rhIGF-I on bone and permit pure osteoblast stimulation. For example, estrogen deficiency was present in the postmenopausal women studied by Ebeling et al. and may have potentiated the effects of IGF-I to stimulate osteoclasts and enhance bone resorption $(52,53)$. Estrogen deficiency was not present in our young female population and this may help to explain why rhIGF-I administration did not effect bone resorption. Treatment of bone cells with IGF-I in vitro increases production of interleukin-6 (IL-6), a cytokine which is known to stimulate osteoclast formation and bone resorption (49). However, estrogen inhibits IL-6 expression in bone marrow-derived stromal cell cultures and may also act in vivo to modulate the effects of systemically administered rhIGF-I on cytokine production and bone resorption (54). Furthermore, the model of acute fasting to alter endogenous IGF-I levels in our population is significantly different from the nutritionally replete population previously studied. A final explanation for our findings is that an effect on bone resorption may lag behind the immediate effects of rhIGF-I on bone formation in the fasting state.

This study demonstrates that bone turnover falls rapidly during short-term fasting in normal women and that administration of rhIGF-I acts to selectively stimulate bone formation in this setting. Although further studies are needed to fully elucidate the mechanisms by which bone turnover responds to acute changes in nutritional status, we have demonstrated the potent effects of IGF-I to uncouple bone formation and resorption in women undergoing short-term fasting. These data suggest that rhIGF-I administration should be investigated as a novel therapy to selectively increase bone formation and bone mass in conditions of chronic undernutrition such as anorexia nervosa, or, low bone turnover.

\section{Appendix} inine]

1. GFR $(\mathrm{ml} / \mathrm{min})=[$ urine creatinine $][$ urine volume $] /[$ serum creat-

2. Diffusible calcium $=[$ ionized calcium $](1.1)$

3. Renal calcium filtration $(\mathrm{mg} / \mathrm{min})=($ GFR $)$ (diffusible calcium)

4. Renal calcium reabsorption $(\mathrm{mg} / \mathrm{min})=$ renal calcium filtration - urinary calcium excretion

5. Fractional reabsorption of calcium $(\%)=$ renal calcium reabsorption/renal calcium filtration

\section{Acknowledgments}

The investigators thank the nurses and dietary staff at the General Clinical Research Center for their dedicated patient care, Dr. David Schoenfeld for biostatistical advice, Dr. Joel Finkelstein for his helpful suggestions with the manuscript, Ms. Helen Bikkal for technical assistance, and Genentech for providing rhIGF-I.

This work was supported in part by National Institutes of Health grants M01-RR01066, F32-DK08783, and P32-DK07028. Dr. Baum is a recipient of the Daland Fellowship of the American Philosophical Society.

\section{References}

1. Bennet, A., T. Chen, D. Feldman, R. L. Hintz, and R. G. Rosenfeld. 1984. Characterization of insulin-like growth factor I receptors on cultured rat bone cells: regulation of receptor concentration by glucocorticoids. Endocrinology. 115:1577-1583.

2. Canalis, E. 1980. Effect of insulin-like growth factor I on DNA and protein synthesis in cultured rat calvaria. J. Clin. Invest. 66:709-719.

3. McCarthy, T. L., M. Centrella, and E. Canalis. 1989. Regulatory effects of insulin-like growth factors-I and II on bone collagen synthesis in rat calvarial cultures. Endocrinology. 124:301-309.

4. Schoenle, E., J. Zapf, R. E. Humbel, and E. R. Froesch. 1982. Insulin-like growth factor I stimulates growth in hypophysectomized rats. Nature (Lond.). 296:252-253.

5. Hock, J. M., M. Centrella, and E. Canalis. 1988. Insulin-like growth factor I has independent effects on bone matrix formation and cell replication. Endocrinology. 122:254-260.

6. Isaksson, O. G. P., A. Lindahl, A. Nilsson, and J. Isgaard. 1987. Mechanisms of the stimulatory effect of growth hormone on longitudinal bone growth. Endocrine Reviews. 8:426-438.

7. Wergedal, J. E., S. Mohan, M. Lundy, and D. J. Baylink. 1990. Skeletal growth factor and other growth factors known to be present in bone matrix stimulate proliferation and protein synthesis in human bone cells. J. Bone Miner. Res. 5:179-186.

8. Canalis, E., M. Centrella, W. Burch, and T. L. McCarthy. 1989. Insulinlike growth factor I mediates selective anabolic effects of parathyroid hormone in bone cultures. J. Clin. Invest. 83:60-65.

9. Ernst, M., and G. A. Rodan. 1991. Estradiol regulation of insulin-like growth factor-I expression in osteoblastic cells: evidence for transcriptional control. Mol. Endocrinol. 5:1081-1089.

10. Linkhart, T. A., and S. Mohan. 1989. Parathyroid hormone stimulates release of insulin-like growth factor I (IGF-I) and IGF-II from neonatal mouse calvaria in organ culture. Endocrinology. 125:1484-1491.

11. Scheven, B. A. A., and N. J. Hamilton. 1991. Longitudunal bone growth in vitro: effects of insulin-like growth factor I and growth hormone. Acta. Endocrinol. 124:602-607.

12. Stracke, H., A. Schulz, D. Moeller, S. Rossol, and H. Schatz. 1984. Effect of growth hormone on osteoblasts and demonstration of Somatomedin-C/IGF-I in bone organ culture. Acta. Endocrinol. 107:16-24.

13. Ernst, M., J. K. Heath, and G. A. Rodan. 1989. Estradiol effects on proliferation, messenger ribonucleic acid for collagen and insulin-like growth factor-I, and parathyroid hormone-stimulated adenylate cyclase activity in osteoblastic cells from calvariae and long bones. Endocrinology. 125:825-833.

14. Goad, D. L., and A. H. Tashjian. 1993. Insulin-like growth factor-I inhibits parathyroid hormone-stimulated and enhances prostaglandin E2-stimulated adenosine $3^{\prime}, 5^{\prime}$-monophosphate production by human osteoblast-like SaOS-2 cells. Endocrinology. 133:1585-1592.

15. Clemmons, D. R., A. Klibanski, L. E. Underwood, J. W. McArthur, E. C. Ridgway, I. Z. Beitins, and J. J. Van Wyk. 1981. Reduction of plasma immunoreactive somatomedin $\mathrm{C}$ during fasting in humans. J. Clin. Endocrinol. Metab. 53:1247-1250.

16. Clemmons, D. R., L. E. Underwood, R. N. Dickerson, R. O. Brown, L. J. Hak, R. D. MacPhee, and W. D. Heizer. 1985. Use of plasma somatomedin$\mathrm{C} /$ insulin-like growth factor I measurements to monitor the response to nutritional repletion in malnourished patients. Am. J. Clin. Nutr. 41:191-198.

17. Isley, W. L., L. E. Underwood, and D. R. Clemmons. 1984. Changes in plasma somatomedin- $\mathrm{C}$ in response to ingestion of diets with variable protein and energy content. Jpn J. Parenter. Enteral Nutr. 8:407-411.

18. Merimee, T. J., J. Zapf, and E. R. Froesch. 1982. Insulin-like growth factors in the fed and fasted states. J. Clin. Endocrinol. Metab. 55:999-1002.

19. Hochberg, Z., P. Hertz, V. Colin, S. Ish-Shalom, D. Yeshurun, M. B. H Youdim, and T. Amit. 1992. The distal axis of growth hormone (GH) in nutritional disorders: GH-binding protein, insulin-like growth factor-I (IGF-I), and IGF-I receptors in obesity and anorexia nervosa. Metabolism. 41:106-112.

20. Counts, D. R., H. Gwirtsman, L. M. S. Carlsson, M. Lesem, and G. B. Cutler. 1992. The effect of anorexia nervosa and refeeding on growth hormonebinding protein, the insulin-like growth factors (IGFs), and the IGF-binding proteins. J. Clin. Endocrinol. Metab. 75:762-7.

21. Fonseca, V. A., V. D'Souza, S. Houlder, M. Thomas, A. Wakeling, and P. Dandona. 1988. Vitamin D deficiency and low osteocalcin levels in anorexia nervosa. J. Clin. Pathol. 41:195-197.

22. Biller, B. M. K., V. Saxe, D. B. Herzog, D. I. Rosenthal, S. Holzman, and A. Klibanski. 1989. Mechanisms of osteoporosis in adult and adolescent women with anorexia nervosa. J. Clin. Endocrinol. Metab. 68:548-554.

23. Saggese, G., S. Bertelloni, G. I. Baroncelli, and G. Di Nero. 1992. Serum levels of Carboxyterminal propeptide of type I procollagen in healthy children from 1st year of life to adulthood and in metabolic bone diseases. Eur. J. Pediatr. 151:764-768.

24. Daughaday, W. H., and P. Rotwein. 1989. Insulin-like growth factors I and II. Peptide, messenger ribonucleic acid and gene structures, serum, and tissue concentrations. Endocrine Reviews. 10:68-91.

25. Ingram, R. T., Y. K. Park, B. L. Clarke, and L. A. Fitzpatrick. 1994. Ageand gender-related changes in the distribution of osteocalcin in the extracellular matrix of normal male and female bone. J. Clin. Invest. 93:989-997.

26. Laron, Z., B. Klinger, L. T. Jensen, and B. Erster. 1991. Biochemical and hormonal changes induced by one week of administration of rIGF-I to patients with Laron type dwarfism. Clin. Endocrinol. 35:145-150.

27. Nicolas, V., A. Prewett, P. Bettica, S. Mohan, R. D. Finkelman, D. J. Baylink, and J. R. Farley. 1994. Age-related decreases in insulin-like growth 
factor-I and transforming growth factor-beta in femoral cortical bone from both men and women: implications for bone loss with aging. J. Clin. Endocrinol. Metab. 78:1011-1016.

28. Sartorio, A., A. Conti, M. Monzani, F. Morabito, and G. Faglia. 1993 Growth hormone treatment in adults with GH deficiency: effects on new biochemical markers of bone and collagen turnover. J. Endocrinol. Invest. 16:893-898.

29. Ebeling, P. R., J. D. Jones, W. M. O'Fallon, C. H. Janes, and B. L. Riggs 1993. Short-term effects of recombinant human insulin-like growth factor-I on bone turnover in normal women. J. Clin. Endocrinol. Metab. 77:1384-1387.

30. Company, M. L. I. 1983. 1983 Metropolitan height and weight tables. Stat. Bull. 64:2-9.

31. Martinez-Maldonadao, M. 1983. Handbook of Renal Therapeutics. Plenum Publishing Corporation, New York. 59.

32. Case records of the Massachusetts General Hospital. 1992. Weekly clinicopathological exercises. Normal reference laboratory values [see comments]. $N$. Engl. J. Med. 327:718-24.

33. Uebelhart, D., E. Gineyts, M. C. Chapuy, and P. D. Delmas. 1990. Urinary excretion of pyridinium crosslinks: a new marker of bone resorption in metabolic bone disease. Bone Mineral. 8:87-96.

34. Branca, F., S. R. Robbins, A. Ferro-Luzzi, and M. H. N. Golden. 1992 Bone turnover in malnourished children. Lancet. 340:1493-1496.

35. Bird, T. A., R. G. Spanheimer, and B. Peterkofsky. 1986. Coordinate regulation of collagen and proteoglycan synthesis in costal cartilage of scorbutic and acutely fasted, vitamin C-supplemented guinea pigs. Arch. Biochem. Biophys. 246:42-51.

36. Gosiewska, A., S. Wilson, D. Kwon, and B. Peterkofsky. 1994. Evidence for an in vivo role of insulin-like growth factor-binding protein-1 and -2 as inhibitors of collagen gene expression in vitamin C-deficient and fasted guinea pigs. Endocrinology. 134:1329-1339.

37. Spanheimer, R. G., and B. Peterkofsky. 1985. A specific decrease in collagen synthesis in acutely fasted, vitamin C-supplemented guinea pigs. J. Biol. Chem. 260:3955-3962.

38. Bagi, C. M., R. Brommage, L. Deleon, S. Adams, D. Rosen, and A Sommer. 1994. Benefit of systemically administered rhIGF-I and rhIGF-I/IGFBP 3 on cancellous bone in ovariectomized rats. J. Bone Miner. Res. 9:1301-1312

39. Martinez, A. J., M. Pascual, and J. Larralde. 1994. Acute effects of insulinlike growth factor-I (IGF-I) on bone protein synthesis in rats. Biochim. Biophys. Acta. 1199:101-103.

40. Conover, C. A. 1992. Potentiation of insulin-like growth factor (IGF) action by IGF-binding protein 3: studies of underlying mechanism. Endocrinology. 130:3191-3199.

41. Ernst, M., and G. Rodan. 1990. Increased activity of insulin-like growth factor (IGF) in osteoblastic cells in the presence of growth hormone (GH) positive correlation with the presence of the GH-induced IGF-binding protein BP3. Endocrinology. 127:807-814

42. Lewitt, M. S., H. Saunders, and R. C. Baxter. 1993. Bioavailability of insulin-like growth factors (IGFs) in rats determined by the molecular distribution of human IGF-binding protein-3. Endocrinology. 133:1797-1802.

43. LeRoith, D., D. Clemmons, P. Nissley, and M. M. Rechler. 1992. NIH conference. Insulin-like growth factors in health and disease [see comments]. Ann. Intern. Med. 116:854-62.

44. Suwanickul, A., S. L. Morris, and D. R. Powell. 1993. Identification of an insulin-responsive element in the promoter of the human gene for insulin-like growth factor binding protein-1. J. Biol. Chem. 268:17063-17068.

45. Peterkofsky, B., J. Palka, S. Wilson, K. Takeda, and V. Shah. 1991. Elevated activity of low molecular weight insulin-like growth factor-binding proteins in sera of vitamin C-deficient and fasted guinea pigs. Endocrinology. 128:1769-1779.

46. Bushinsky, D. A., and N. E. Sessler. 1992. Critical role of bicarbonate in calcium release from bone. Am. J. Physiol. 263:F510-515.

47. Sebastiani, A., S. T. Harris, J. H. Ottaway, K. M. Todd, and R. C. Morris. 1994. Improved mineral balance and skeletal metabolism in postmenopausal women treated with potassium bicarbonate. N. Engl. J. Med. 330:1776-1781.

48. Guler, H. P., K. U. Eckardt, J. Zapf, C. Bauer, and E. R. Froesch. 1989 Insulin-like growth factor I increases glomerular filtration rate and renal plasma flow in man. Acta Endocrinologica. 121:101-106.

49. Slootweg, M. C., W. W. Most, E. van Beek, L. P. C. Schot, S. E. Papapoulos, and C. W. G. M. Lowik. 1992. Osteoclast formation together with interleukin- 6 production in mouse long bones is increased by insulin-like growth factorI. J. Endocrinology. 132:433-438.

50. Condamine, L., F. Vztovsnik, G. Friedlander, C. Menaa, and M. Garabedian. 1994. Local action of phosphate depletion and insulin-like growth factor 1 on in vitro production of 1,25-dihydroxyvitamin $\mathrm{D}$ by cultured mammalian kidney cells. J. Clin. Invest. 94:1673-1679.

51. Kupfer, S. R., L. E. Underwood, R. C. Baxter, and D. R. Clemmons. 1993. Enhancement of the anabolic effects of growth hormone and insulin-like growth factor I by use of both agents simultaneously. J. Clin. Invest. 91:391396.

52. Mochizuki, H., Y. Hakeda, N. Wakatsuki, N. Usui, S. Akashi, T. Sato, K. Tanaka, and M. Kumegawa. 1992. Insulin-like growth factor-I supports formation and activation of osteoclasts. Endocrinology. 131:1075-1080.

53. Turner, R. T., B. L. Riggs, and T. C. Spelsberg. 1994. Skeletal effects of estrogen. Endocrine Reviews. 15:275-300.

54. Pottraz, S. T., T. Bellido, H. Mocharia, D. Crabb, and S. C. Manolagas. 1994. 17 $\beta$-estradiol inhibits expression of human interleukin-6 promoter-reporter constructs by a receptor-dependent mechanism. J. Clin. Invest. 93:944-950. 